УДК 94:37.014(470.64).08

DOI: $10.31007 / 2306-5826-2019-1-40-33-38$

\author{
ПЕРЕД ЛИЦОМ ЯЗЫКОВОГО СДВИГА: \\ РАЗМЫШЛЕНИЯ К ПОЛОЖЕНИЮ \\ ЧЕРКЕССКОГО ЯЗЫКА В ДОШКОЛЬНОМ ОБРАЗОВАНИИ \\ КАБАРДИНО-БАЛКАРСКОЙ РЕСПУБЛИКИ \\ (2000-2014)
}

\begin{abstract}
Алоев Тимур Хазраилович, кандидат исторических наук, старший научный сотрудник сектора средневековой и новой истории Института гуманитарных исследований филиала Федерального государственного бюджетного научного учреждения «Федеральный научный центр «Кабардино-Балкарский научный центр Российской академии наук» (ИГИ КБНЦ РАН), aloborsa@mail.ru

Проблематика защиты языковых прав меньшинств является одной из сфер, в которых проявляется степень сбалансированности межэтнических отношений в сложноустроенных политиях. Об уровне комплиментарности последних к лингвистическим запросам миноритарных сообществ можно безошибочно судить по степени включенности тех или иных языков в государственную систему образования.

В фокусе настоящего исследования оказывается положение черкесского языка в одном отдельно взятом сегменте системы образования в Кабардино-Балкарской Республике. Аналитическая оптика направлена на выяснение условий функционирования черкесского языка в дошкольных образовательных учреждениях республики. Исследовательская перспектива выстраивается на соотнесении наличествующих в республике институциональных ресурсов, демографического потенциала и лингвистического запроса населения на всестороннее изучение черкесского языка и де-факто реализуемой в рамках системы образования курса на профанацию идеи полилингвального обучения.
\end{abstract}

Ключевые слова: черкесский язык, дошкольное образование, Кабардино-Балкарская Республика, институциональная инфраструктура.

Одно из распространенных в лингвистике определений языка гласит, что это исторически сложившаяся система звуковых, словарных и грамматических средств, объективирующая работу мышления и являющаяся орудием общения, обмена мыслями и взаимного понимания людей в обществе. Однако полноценное функционирование этой системы возможно лишь при условии социальной (экономической, политической, демографической и т.д.) стабильности, практикующей тот или иной язык популяции. Одним из ключевых параметров, выражающих устойчивость социума в лингвистическом отношении и одновременно определяющим фактором витальности языка, выступает качество инфраструктуры его межпоколенной трансмиссии. В условиях современных урбанизационных процессов и стандартизации повседневной жизни модусы передачи культурного багажа, в том числе языковых компетенций от старших к младшим поколениям, претерпевает существенные, порой кардинальные изменения. Очевидно, что центр тяжести в процессах социализации личности переместился от семьи/ округи/общины в сторону системы государственного образования. В этой связи не случайно, что базовым институтом культурной трансмиссии в современной социологии признана система образования, обеспечивающая передачу культурного багажа от старших поколений (воспитатели дошкольных учреждений, учителя 
школ, преподаватели высшей школы) к младшим (от дошкольников до студентов) посредством санкционированных государством механизмов обучения. В РФ данная система, как и в большинстве стран, градуируется несколькими уровнями (дошкольное, начальное, школьное и т.д.). От налаженного преподавания языка на каждом из них, в конечном итоге, и зависит степень языковой компетенции каждого нового, вступающего во взрослую жизнь поколения. Вместе с тем, следует подчеркнуть особую роль, которая возложена на систему дошкольного образования в деле гарантированной качественной передачи языковых навыков. На лингвосоциальных аспектах ее функционирования в Кабардино-Балкарской республике (КБР) сосредоточивается внимание настоящего текста. При этом следует оговориться, что анализируемая здесь ситуация и фактология целиком относятся к периоду предшествовавшему дискриминационному крену, обозначившемуся в действиях Москвы с середины 2017 г. (выступление В. Путина в Йошкар-Оле относительно необходимости преференций для русского языка, антиконституционный закон, направленный на подрыв миноритарных языков в республиках, принятый Государственной Думой летом 2018 г., закрепление «особого» статуса русского народа в концепции национальной политики РФ, принятой осенью 2018 г., выделение 80 млн. рублей на «поддержку» миноритарных языков РФ, тогда как на развитие условий функционирования русского языка в 2018-2020 гг. планируется затратить более 7 млрд. рублей). Представляется, что исследование ситуации, сложившейся до текущей фазы этноязыковой турбуленции, позволит выстроить максимально корректную оптику анализа.

Прежде всего следует артикулировать значение дошкольного возраста с точки зрения обеспечения эффективного вовлечения детей в стихию родного языка. Овладение родным языком, развитие речи является одним из самых важных приобретений ребенка в дошкольном возрасте и рассматривается в современном дошкольном воспитании как общая основа воспитания и обучения детей. И здесь важным элементом механизма полнокровной передачи языковых компетенций наряду с семьей связующим звеном между родителями и детьми в процессе освоения родного языка выступает или должен выступать детский сад, в который ребенок попадает в период бурного развития его когнитивных способностей. Соответственно, дошкольный возраст - это период, когда дети активно усваивают разговорный язык. Как известно, в этом возрасте ребенок осваивает все разнообразие окружающей языковой стихии (фонетику, лексику, грамматику). Полноценное овладение родным языком в дошкольном возрасте является необходимым условием для решения задач умственного, эстетического и нравственного развития, а также последующей полноценной социализации. Однако этот, характеризующийся гиперспособностью к восприятию и ускоренному закреплению нового знания период весьма краток. Уже к 6-7 летнему возрасту пластичность нервной системы начинает существенно снижаться (до недавнего времени полагали, что такая благоприятная фаза у ребенка продолжается до 11-12 летнего возраста) и это сказывается на способности к развитию когнитивных навыков, в частности, языковых.

В случае, если упускается промежуток жизни ребенка, когда мозг максимально пластичен и способность создания новых нейронных связей и выстраивания релевантных внешней среде репрезентаций отличается наивысшими показателями, полноценное восполнение этого пробела в будущем становится невозможным. Относительно языковых компетенций, в таком случае можно говорить если не о нейрофизиологическом зиянии, то по меньшей мере о мало поддающихся полноценной коррекции когнитивных дефектах.

Эти обстоятельства подвигли к попытке выяснения степени адекватности системы дошкольного образования в КБР современным вызовам по обеспечению полилингвального образования на базе инклюзивной языковой политики. 
Кабардино-Балкария, с ее 2/3 черкесского населения (удельный вес которого продолжает расти) представляет собой мощный в демографическом, культурном и интеллектуальном отношениях анклав черкесов на Северном Кавказе. Более того, с момента обрушения тоталитарной системы демографическое давление нетитульного населения существенно спало (с $38 \%$ до примерно 20\%) и продолжает снижение. Если в 50-х гг. ХХ в. удельный вес черкесов в столице республики едва превышал десятипроцентную отметку, то сегодня Нальчик - город уже с преимущественно черкесским населением. Черкесская идентичность в республике обладает мощной инфраструктурой самоподдержания не только в виде десятков крупных сел (с населением от 5 до 15 с лишним тысячами жителей в каждом). Она устойчиво регенерируется и с опорой на сеть малых (по российской шкале) городов с десятками тысяч жителей (Баксан, Нарткала, Терек, Чегем, Залукокоаже).

На этом фоне наличие институциональных инструментов (продекларированный на конституциональном уровне статус государства, Главы и Парламента республики и т.д.) защиты этнокультурных интересов, казалось, обещало безболезненное, гарантированное поддержание языковых и идентитарных основ развития республики. Однако сложившиеся к исходу первого десятилетия XXI в. реалии были таковы, что образование на родном языке не было налажено ни в начальной, ни в средней и тем более высшей школе. Как следствие (и во многом сопутствующее явление) черкесский язык не стал рабочим ни в делопроизводстве, ни в экономике и политике. Более того, при ознакомлении с открытыми сведениями, относящимися к сферам, в которых формируется инфраструктура культурного суверенитета народа, обнаруживаются явные провалы ведомств, отвечающих за образование и культуру в КБР. Не вдаваясь в анализ всего спектра направлений, требующих кардинального пересмотра принципов и методов работы, укажем лишь на пример культурного нигилизма со стороны республиканских ведомств в одном конкретном сегменте системы образования.

Согласно данным Росстата за 2011 г., в КБР зафиксировано 15 дошкольных учреждений, то есть детских садов, в которых работа велась на черкесском языке ${ }^{1}$ В Республике Татарстан, которая с момента краха Советского Союза выступает флагманом по продвижению принципов федерализма и защите языковых и культурных прав республик в РФ, в это время зафиксировано 1544 подобных учреждений ${ }^{2}$. Разница в тысячу раз (sic!) Это при том, что численность татар в Татарстане лишь в четыре раза превышает данный показатель у черкесов в КБР.

Для полноты и объективности взгляда на ситуацию уместно обратиться к более близкому (по крайней мере географически) примеру соседней с КБР Республики Северная Осетия-Алания ${ }^{3}$. Хотя эта республика ни демографически, ни экономически не сопоставима с Татарстаном, количество дошкольных учреждений с осетинским языком воспитания в 2011 г. там достигло 199. Это при том, что численность осетин уступает черкесскому населению в КБР.

Показательно, что цифровые показатели 2011 г. находятся в явственной корреляции с последующими стратегиями в области языкового строительства, продемонстрированными вышеуказанными республиками.

Так, с февраля 2012 г. в Татарстане стартовала программа по изучению государственных языков в дошкольных учреждениях. В соответствии со «Стратегией развития образования в Республике Татарстан на 2010-2015 годы «Киләчәк» «Будущее» творческой группой, созданной Министерством образования и науки Республики Татарстан, разработан учебно-методический комплект по обучению детей двум государственным языкам в дошкольных образовательных учреждениях Республики Татарстан ${ }^{4}$.

В целях успешного внедрения учебно-методического комплекта в дошкольных образовательных учреждениях, в 2011-2012 учебном году Министерством образования и науки Республики Татарстан подготовлены тьюторы по обучению 
татарскому языку русскоязычных воспитателей дошкольных образовательных учреждений по специально разработанной программе 5 .

Второй пример. На заседании комиссии, которое прошло под руководством Главы республики Северная Осетия-Алания В. Битарова, обсуждались итоги реализации мероприятий государственной программы «Национально-культурное развитие осетинского народа» на 2018-2020 годы за первое полугодие текущего года. О поэтапном внедрении полилингвальной (осетинско-русской) модели образования в школы и детские сады республики рассказала министр образования и науки И. Азимова. С нового учебного года обучение и воспитание по этой системе планируется внедрить в 16 школьных и 23 дошкольных учреждениях Владикавказа и районов. Как подчеркнула Азимова, со временем перечень учебных заведений будет расширяться ${ }^{6}$.

В Кабардино-Балкарии усилия республиканских ведомств в последние годы сводятся лишь к тому, что «в дошкольных группах занятия по изучению родного языка проводятся в игровой форме 2 раза в неделю. Длительность занятий составляет 20-30 минут» ${ }^{7}$.

Ретроспективный взгляд на ситуацию с родным языком в дошкольных учреждениях за декаду до 2011 г. также удостоверяет в преобладании тревожных тенденций в этой сфере. Весьма красноречивыми в этом плане представляются данные социолингвистических опросов, проведенных среди старшеклассников в 2001 г. Согласно этим результатам, лишь 28,9 \% из них ходили в детский сад с русским языком воспитания. В том же году $22,2 \%$ респондентов посещали детский сад с родным языком воспитания ${ }^{8}$. В ходе проведенных опросов было выявлено, что 41,9\% опрошенных посещали дошкольное учреждение с родным и русским языком воспитания. В последующем ситуация существенно изменилась, что позволило инициаторам опроса утверждать, что «в дошкольных учреждениях в 2001 г. болышее количество опрошенных... воспитывались в условиях двуязычной среды» ${ }^{9}$.

Обозначившаяся тенденция к деградации дошкольного образования на родном языке тем удивительнее, что республиканские институции открыто игнорируют языковые запросы населения. Такое заключение проистекает из данных, предоставленных в 2014 г. образовательными учреждениями г. Нальчик относительно языковой компетенции детей дошкольного возраста. Согласно этим сведениям, $82 \%$ черкесских детей дошкольного возраста говорили на родном языке. Доля понимающих, но затрудняющихся разговаривать на нем составляла $12 \%$. И лишь $6 \%$ детей совсем не владели черкесским языком ${ }^{10}$. Подобная статистика позволяет заключить, что сложилась ситуация, характеризующаяся явной раскоординированностью между лингвокультурными запросами/стратегиями населения и системой институций, призванной обеспечить их полнокровную реализацию.

Необходимость адекватного понимания истоков и инструментов профанации идеи создания полноценной системы образования на родном языке, обнаружившейся при обращении к статистическим сведениям, побуждает к выяснению хотя бы наиболее рельефно выраженных черт деструктивной институциональной активности. Если попытаться хотя бы пунктирно обозначить ее динамику, которая в конечном итоге купировала все интенции к ренессансу черкесского языка, можно в качестве отправной точки обратиться к первым отчетливым шагам республиканской власти в условиях перестроечной либерализации и под нажимом демократической общественности. В частности, можно упомянуть приказ Министерства народного образования КБАССР «О введении обучения родным языкам в национальных детских садах (группах) в КБАССР (Приказ № 279 от 18 августа 1989 г. $)^{11} .17$ января 1990 года данное ведомство подготовило другой документ «О мерах по повышению роли родных языков в учебно-воспитательном процессе общеобразовательных школ, профтехучилищ и дошкольных учреждений г. Нальчика» ${ }^{12}$. Однако уже тогда, согласно выводам исследователей, обозначилось «саботирующее» отношение многих управленцев к подобным инициативам ${ }^{13}$. 
Хотя тезис о том, что функционирование языка в системе образования представляет собой «важнейший аспект, ибо обучение на языке обеспечивает его выживание и развитие» ${ }^{14}$ давно стал аксиомой в языкознании, властные институты, не подотчетные населению, редко проявляют склонность к тратам, мотивированным идеалистическими соображениями. Судьба черкесского языка стала наглядным тому подтверждением. К 1997 году, когда национально-демократическое движение, инициировавшее в свое время политику языкового возрождения черкесов, в силу ряда причин потеряло былую мощь, «процесс перехода на родной язык обучения постепенно свернулся» ${ }^{15}$.

И хотя лишь годом ранее в КБР была утверждена «Государственная Программа развития языков народов Кабардино-Балкарской Республики» с многомиллионным бюджетом, рассчитанной на десять лет, к концу этого срока ситуация, наоборот, ухудшилась.

Как справедливо отмечается в одной из работ, новая редакция закона «О языках народов КБР», изданная в марте 2003 г., явственно ограничила функциональное поле черкесского языка. Так, в нее не был включен пункт 3 статьи прежней редакции 1994 г., где говорилось, что «официальные документы, удостоверяющие личность гражданина или сведения о нем, оформляются с учетом национальных традиций именования, специфики языков народов Кабардино-Балкарской республики» ${ }^{16}$. Здесь же отмечается, что статьи 14 и 15 новой редакции закона «О языках» официальную переписку между учреждениями и организациями, а также судопроизводство и делопроизводство в судах и правоохранительных органах предписывают вести только на государственном языке РФ, тем самым исключив возможность использования черкесского языка для этих целей, что предусматривалось в редакции 1994 года ${ }^{17}$.

Закон об образовании, принятый в 2013 г., также в значительной степени дезавуировал достижения в языковой сфере в первой половине 1990-х гг. Разумеется, на фоне такого устойчивого тренда политико-правового отторжения интенций к полноценному лингвистическому равноправию кризис с обучением родному языку в системе дошкольного образования подтверждает сложившийся в республике неблагоприятный языковой режим для носителей черкесского языка.

\section{Примечания}

1. Образование на языках народов России // https://ru.wikipedia.org/wiki/ Образование на языках народов России (дата обращения: 20.09.2018).

2. Там же.

3. Там же.

4. «Новые подходы в обучении детей двум государственным языкам - русскому и татарскому в дошкольных образовательных учреждениях Республики Татарстан»// https:// gigabaza.ru/doc/98749.html (дата обращения: 20.10.18); Направления Стратегии развития образования «Килэчэк» - «Будущее» 2010-2015 гг. // mon.tatarstan.ru/rus /file/pub456134. pdf.

5. Галяутдинова Л.Р. Обучение государственным языкам в дошкольных образовательных учреждениях как основа формирования культуры толерантности // https://infourok.ru/statya - obuchenie - gosudarstvennim - yazikam - v - usloviyah - dou 44761. Html

6. Образование на двух языках введут в Северной Осетии // https://sputnik - ossetia.

7. Башиева С.К., Улаков М.З., Хамдохова Ж.М. Языковая ситуация в Кабардино-Балкарской республике: состояние и проблемы. Нальчик, 2016. С. 116.

8. Там же. С. 119.

9. Там же. С. 120.

10. Там же.

11. Там же. С. 36.

12. Там же. С. 38.

13. Там же. С. 36. 
14. Гак В.Г. К типологии форм языковой политики // Вопросы языкознания. 1989. № 5. C. 130.

15. Башиева С.К., Улаков М.З., Хамдохова Ж.М. Указ. соч. С. 114.

16. Мирзаканова Е.А. Современные этноязыковые процессы и проблема сохранения языка // Вестник КБИГИ. Нальчик, 2004. Вып. 11. С. 137.

17. Там же.

\title{
FACING A LANGUAGE SHIFT: REFLECTIONS ON THE POSITION \\ OF THE CIRCASSIAN LANGUAGE IN PRESCHOOL EDUCATION IN THE KABARDINO-BALKARIAN REPUBLIC
} (2000-2014)

\begin{abstract}
Aloev Timur Khazrailovich, Senior Researcher of the Department of Medieval and Modern History of the Institute for the Humanities Research - Affiliated Federal State Budgetary Scientific Establishment «Federal Scientific Center «Kabardian-Balkarian Scientific Center of the Russian Academy of Sciences» (IHR KBSC RAS), aloborsa@mail.ru

The issue of the protection of the linguistic rights of minorities is one of the areas in which the degree of balance of inter-ethnic relations in complex polities is manifested. The level of complementarity of the latter to the linguistic needs of minority communities can be accurately judged by the degree of involvement of certain languages in the state education system.

The focus of this study is the position of the Circassian language in one particular segment of the educational system in the Kabardino-Balkarian Republic. Analytical optics is aimed at clarifying the conditions for the functioning of the Circassian language in preschool educational institutions of the republic. The research perspective is built on the correlation of the institutional resources available in the republic, the demographic potential and the linguistic demand of the population for a comprehensive study of the Circassian language and the de facto course of profanation of the idea of multilingual education implemented within the educational system.
\end{abstract}

Keywords: Circassian language, preschool education, Kabardino-Balkarian Republic, institutional infrastructure.

DOI: 10.31007/2306-5826-2019-1-40-33-38 